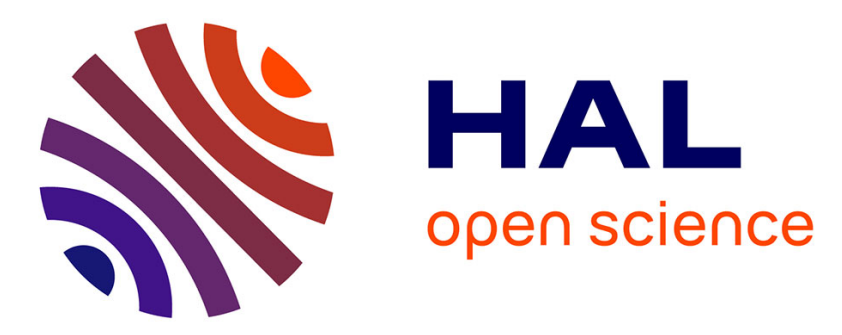

\title{
The politics of territorial networks policies: the example of videocommunication networks in France
}

\author{
Emmanuel Négrier, Judith Crews
}

\section{To cite this version:}

Emmanuel Négrier, Judith Crews. The politics of territorial networks policies: the example of videocommunication networks in France. Flux - Cahiers scientifiques internationaux Réseaux et territoires, 1990, 6 (1), pp.13-20. 10.3406/flux.1990.1170 . hal-02468850

\section{HAL Id: hal-02468850 \\ https://hal.science/hal-02468850}

Submitted on 6 Feb 2020

HAL is a multi-disciplinary open access archive for the deposit and dissemination of scientific research documents, whether they are published or not. The documents may come from teaching and research institutions in France or abroad, or from public or private research centers.
L'archive ouverte pluridisciplinaire HAL, est destinée au dépôt et à la diffusion de documents scientifiques de niveau recherche, publiés ou non, émanant des établissements d'enseignement et de recherche français ou étrangers, des laboratoires publics ou privés.

\section{(ㅇ)(1) $\$$}

Distributed under a Creative Commons Attribution - NonCommercial - NoDerivatives| 4.0 


\section{The politics of territorial networks policies: the example of} videocommunication networks in France

\section{Emmanuel Négrier, Judith Crews}

\section{Citer ce document / Cite this document :}

Négrier Emmanuel, Crews Judith. The politics of territorial networks policies: the example of videocommunication networks in France. In: Flux, n¹, 1990. pp. 13-20;

doi : https://doi.org/10.3406/flux.1990.1170

https://www.persee.fr/doc/flux_1154-2721_1990_num_6_1_1170

Fichier pdf généré le 12/05/2018 


\begin{abstract}
The rise in power of electronic communications networks, audiovisual and telecommunications in France is based on a complex arrangement of actors on the local and national level. For the researcher, this rise raises the question of the relationship between networks and territories. Far from being regulated by a simple technical approach, this relationship brings to light a dialectics of territorialization. Within the context of the crisis of specialized executives in the area of public intervention (crisis of the State-nation, decentralization), this dialectic combines the heterogenous representations and practices of territories and the networks which structure them. The French "PlanCâble" is a good illustration of this. As a result, the political and territorial dimension, far from being a negligible part of these technical projects, is in fact right at the center of network implantation. An analysis in. terms of territorial networks gives rewarding results.
\end{abstract}

\title{
Résumé
}

La montée en puissance des réseaux de communication électronique, de l'audiovisuel et des télécommunications, repose en France sur un agencement complexe d'acteurs locaux et nationaux. Elle pose au chercheur la question du rapport réseaux-territoires. Loin d'être réglé par une simple approche technique, ce rapport met en lumière une dialectique de la territorialisation. Dans un contexte de crise des cadres spatialisés de l'intervention publique (crise de l'Etat-nation, décentralisation), cette dialectique combine des représentations et pratiques hétérogènes du territoire et des réseaux qui les dimensionnent. Le Plan-Câble français en est une bonne illustration. Du coup, loin d'être une partie négligeable des projets techniques, la dimension politique et territoriale est bien au coeur des implantations de réseaux. C'est toute la richesse d'une analyse en termes de réseaux territoriaux. 


\section{THE POLITICS OF TERRITORIAL NETWORK POLICIES: THE EXAMPLE OF VIDEOCOMMUNICATIONS NETWORKS IN FRANCE}

Emmanuel NEGRIER, Doctor in Political Science, is currently teacbing and doing research at the C.E.P.E.L. (Cen tre d'Etudes des Politiques publiques et des Espaces Locaux) of the Univer. sité de Montpellier I on the public policies in audiovisual and telecommunications.
The relationship established here between network and territory is not self-evident. Whereas a network can be defined as "the physical and/or social connecting together of dispersed elements"1, its dynamic is essentially based on an indifference to the notion of boundaries. On the con. trary, a territory is constituted precisely by its capacity to contain or limit a particular space within a global space. The many dimensions of the notion of territory are thus built upon what the network rejects. The boundary gives significance to a territory because it encloses, but also because it is the prerequisite to opening. The boundary is its means of communication.

There are numerous examples of the antagonism between territory and network. As a matter of fact, the development of technical networks, in the large majority of cases, includes a challenge to the significance of the traditional administrative territory. The history of intercommunity relations, for example, is closely associated with that of the development of urban technical networks ${ }^{2}$. Telecommunica. tions networks contribute in their own way to the uncertainty in territoriality which results from the activity of networks. The Conseil Constitutionnel censured the legislators in 1984, and the legislators responded in like manner; this situation clearly demonstrates the difficulty encountered in trying to impose territorial limits on a network, in this particular case the cable network ${ }^{3}$.

Thus we should really be writing two separate accounts here, one for technical networks and the other for ter. ritories. If this were so, however, to think in terms of policies governing the relationship between networks and territories would immediately become meaningless; a radical logical contradiction would prevent any reconciliation between the two. Nevertheless, the notion of "ter. ritorial network" does make sense, as we shall demon. strate. 
The essential contribution of networks to the formation of territories is to be found in the history of techniques. Under the reign of Louis $\mathrm{XIV}$, the role of the administration in the arrangement of space into networks prefigured the bourgeois order to come, with its unified, homogeneous territory 4 . The French Revolution itself, when it set about organizing territory and cartography, determined boundaries according to the quality of networks of communication', and the battles of local representatives concerned the greater or smaller capacity for interaction among different towns ${ }^{6}$.

Later, when it became a question of the development of the railroads, the stakes extended beyond the merely industrial sector, to become, according to $M$. Chevallier, "a political revolution"7. Here, networks were not only the indica. tion of change in the relation between time and space, but also the vector of political projection onto territory. As such, they contributed to the consolidation and reproduction of the State. nation and of territory in the founding of its functional superiority. In this mode of specific relationship, where we have set up the hetero. geneity of the two terms, along with their necessary combination, network and territory are indeed the object of a regulation, or policy. This policy is located directly within the idea of the nation, not simply in its symbolic dimension, but in its concretization and naturalization. It is the "real fiction" represented by this policy which orders the unification of networks around territory, and likewise links administrative territories according to homogeneous and network-like technical knowledge. Moreover, this knowledge is exported, with the exportation of the model of the State-nation, in the theory and practice of colonialism $^{8}$.

The territorial basis for networks in fact depends upon a national mode of integration of know. ledge and representation. During the period of the trente glorteuses 9 , the corps of the Ponts et Cbaussées and the methods it used for territorial ramification constituted a privileged domain for political analysis ${ }^{10}$. The concept of mixed policies is, beyond the impoverishing institutional perspectives which it presents, the best means of concretely understanding the social, technical and political links between networking knowledge and territorial representations. Based on the norms of general interest, the exchange of political and technological administrative resources gives birth to an autonomous system, just as it reproduces the State-nation while making it concrete. With respect to telecommunications networks, the installation of the telephone according to the wishes of the local political elite ${ }^{11}$ provides a good exmple of the effects of this policy.

The crisis of the network-territory relationship has become established at the three possible elements where they cross. First, the crisis of the State-nation itself, and of its capacity to insure a correspondence between the seat of economic exchange and the space of social policy ${ }^{12}$. Secondly, it is also the crisis of territory, of its capacity to reproduce this relationship in an autonomous and combined mode. Finally, this crisis may remain with the networks. This perturbation can be expressed in terms of succession. For I. Gokalp, the peculiarity of social communication networks is that they are established in accordance with a slow absorption of the net. works which preceded them ${ }^{13}$. The synthesis is based upon a fecundation between networks, but also between networks and territories. The ques. tion which arises as new telecommunications networks develop concerns the persistence of this necessary link. How and in what way would these contain a radical deterritorialization? The answer may be that the emergence of networks is articulated, in the Plan-cable, or "cable-plan", in particular, over a territory which already possesses technical resources ${ }^{14}$. The interpretation of the paradox, according to $\mathrm{Y}$. Barel ${ }^{15}$, is in fact related to a movement of deterritorialization. reterritorialization, creating a need for territory at the very moment it dissolves. A more radical option is defended by B. Stieger ${ }^{16}$. The develop. ment of new communication services here calls the future of the notion of territory directly into question. Postulating reflexivity as the founding element, he detects in the progressive domination of a synthetic concept of temporality (real time) the negation of the distance (delay) which consti. tutes territory. The new networks would have as their characteristic the introduction of a general crisis in the sense of adherence. The passage from organic, territorial solidarity to mechanical, 
networking solidarity would be all the more powerful in that it would be linked to the clinical and reassuring concept of the network ${ }^{17}$.

The diagnosis thus established for the end of territories as such as networks become estab. lished comes back to the significance of models founded on this necessary policy. The attacks to be henceforth sustained by the concept of mixed policies participates in this particular crisis ${ }^{18}$. What this has allowed us to discover, in the margins of the law, contributed at the same time to masking singular processes, which functioned "locally" but extended much more globally. These participate, according to $\mathrm{M}$. Abeles, to a linking of social and political networks which mark territories of action and representation. Extending to the analysis of public policies of communica. tions networks, the utilization of the concept of network might appear quite simply as one of the tautologies of $\mathrm{Sfez}^{19}$. Networks, encountering networks, form other networks.

However, it seemed to us that this "drift" might at the same time presuppose a homogeneity between technical, political and social networks. In other words, the self regulation of social matters by networks implies a generalized domination of "real time." This is also implicitly to give to technical matters the capacity to legitimate by them. selves the social matters which they inform. B. Stieger's pessimistic voluntarism meets its equal here only in M. MacLuhan's frank optimism.

Now, it is precisely in the heterogeneity of networks constituting a specific urban history that a renewed interrogation of the network-territory policy can be placed. The setting up of a cabletelevision network in France is the terrain which will be examined here.

\section{The French Plan-able between network(s) and territory(les)}

The French Plan-câble was decided upon in November, 1982, by the Socialist government of P. Mauroy. After an experimental phase of television distribution in the 1970's, limited to a few cities and rapidly abandoned, mainly because of resistance from the local daily press, the Plan was presented as a volontary method for equipping the entire national territory. A technology based on the utilization of optical fibres and "star. shaped" architecture, contrary to cable distribu. tion, was supposed to allow the development of interactive communication services not strictly limited to television. In its initial version, which lasted officially up until the change in government in March, 1986, the French telecommunications administration held a monopoly on building and owning the networks. It simply conceded, as for telematics but contrary to the telephonic mode, the commercial management of television services offered to the public.

The establishment of a policy for cable, simultaneous with the laws on decentralization, was to emphasize the role of local groups in putting the plan into action. The local mixed economy, which let territorial executives and private capital be associated, was to be the only formula authorized by the legislators, "haunted" as it were by the risks of the privatization of audiovisual and telecommunications as contained in the Plan. The development of the networks was to depend on elected officials (under whose initiative fell local programming) and the administration, which registered and dealt with local solicitations on a centralized level.

At the outset, there was a multiplication of local companies for cable exploitation (S.L.E.C.), which grouped together the different public and private partners (except for the Direction Générale des Télécommunications, or DGT). These companies were in charge of determining zones, tariffs and programs for the local service plans. They also put into operation the reflection on the (required) installation of programming and local production.

Beginning in 1985, locally-elected officials withdrew from the risks involved in cable, and conceded to privately operated companies the effec. tive management of commercialization. This shift in practice was made official by new regulations (law of 30 September 1986) which allowed local groups to confide the management of cable to a company (without specifying whether it be pub. lic, private, or a combination of the two), in the same way that it ended the public monopoly over 
building and owning the networks.

The new policy framework for cable would encourage an explosion in the demand for cable from local authorities, and a breaking-up of the plan for equipment into the different procedures and technologies of cabling. Optical fibre, aban. doned by the DGT as early as 1985, except for a few experimental sites, left the field open for coaxial cable and, more rarely, for new techniques like "double-wire" (video-communication using telephone connections, a system promoted by the company VISICABLE PLUS). The architec. ture of the networks remained mostly the star. shaped structure, even if newer approaches tended to get away from the overall approach represented by this method (networks in the form of mini-star for the company REGION CABLE in Nice; or, again, the system of preliminary collective equipment at the outset of the network, for the company CG-SAT of the group Compagnie Générale des Eaux).

The liberalization of the legal framework and the multiplication of technical procedures for cable were an attempt to respond to the lack of public enthusiasm for cable, associated with the weight of the plan as well as its cost. Three years later, subscriptions have not substantially increased: they tend to stagnate at around $15 \%$ of commercial penetration, on the average.

The French cable landscape today thus resembles a patchwork quilt where the following elements co-exist:

- Traditional teledistribution, left over from the 1973 experiments (Metz and Nice, for exam. ple);

- Networks faithful to the Plan-cable (Montpellier and Rennes, for example);

- Networks of the "liberal era" (starting in 1986) like the projects in Chalon-sur-Saóne (Lyonnaise Communication), Sète (Compagnie Générale des Eaux) or Clermont-Ferrand (COmmunication).

These networks, whatever their technical or legal nature, are exclusively destined for televisual communication. New telecommunication services (Pay per view, "televideotheque", visiophone, data exchange, etc.) have become technically delicate or even impossible in most cases, and are the object of a still unresolved polemic between administration and commercial operators in those places where the services might be accessible (as in Montpellier).

The case of the 1982 French Plan for cable illustrates perfectly the complexity of the process of territorial policies in communication networks. We shall insist here on the multiple representa. tions of the territory of intervention of partners and on the methods, which are specifically French $^{20}$, of the territorialization of networks.

The Plan-cáble, such as it was defined in Novem. ber 1982, corresponds at one and the same time to the logical evolutions of interdependence of technical networks brought into evidence by $I$. Gokalp, and to the a-territorial domination of real time. In its encompassing version, it prefigures and constitutes the infrastructure of a society whose radical newness would in fact be... to be "network-able"21. Indeed, the program set itself the task of equipping the entire territory with a unique network which constitutes the synthesis of two, or even three distinct networks: telephone, telematic, and the Herzian network. The services linked to these networks, which have reached a stage of maturity, not to say saturation, have retreated into a forbidden network. As we have seen above for the railroad, the announce. ment of the plan-câble was accompanied by a political discourse of rupture: cable is at one and the same time, largely thanks to optical fibre, an instrument of communication and of local demo. cracy, a revolution in habits, the focal lever for a new industrial revolution... to say nothing of the future victories carried away by French telecom. munications in the world battle which is to come in this high-tech sector.

Of interest here is to determine what will become of this discourse in the practices of setting up networks ${ }^{22}$. To begin with, in the initial contact between administration and local authorities, the inflationary reproduction of "revolutionary" dis. course takes precedence. Elected representatives use the network as the emblematic incarnation of their projects of development. Optical fibre, and the metaphors associated with it (the obscuran- 
tism of coaxial cables vs. the Enlightenment of optical), fascinates communities as much as the administrative agents who are going to put it in place. During the second stage, however, the network takes form in the framework of the urban networks.

First of all on a physical level, cable finds itself confronted with the complex and thousand-year old history of technical networks. The costs of civil engineering have to be considerably increased with respect to what was foreseen. In addition, as in Montpellier, the specific properties of optical fibre are going to mean that considerably more is going to be spent than was bud. geted $^{23}$.

But it is especially in the political integration of these networks into the urban system that the different apprehensions of the territory become evident. Whereas the diagram at the outset foresaw the pairing of Administration with elected representatives as the mainspring of cable, it is the duel between France Télécom ${ }^{24}$ and the private operators which has little by litule come to dominate public policy. There are numerous hypotheses which attempt to explain this "cable war."

The administration, judged to be rigid and rash in its strategic choices, seems economically to behave negatively, with respect to private forces, who are the partners and potential competitors of tomorrow concerning services with additional value. It is a fact that numerous examples demon. strate the incapacity of France Télécom to soften its apprehension of the dossier. Its methods of commercialization by employing unweildy work blocks; its rigidity in fuxing rates (the indifference of its rates with respect to urban density and to the type of dwelling, when the real costs involved are very different...); the naivete of certain agents in their technological choices: all these are the criticisms which are generally addressed to France Télecom.

Inversely, the private operators are accused of investing in cable with no real knowledge of the network, nor any prerequisite experience in interpersonal communication. In addition, the financial interest in itself of these companies raises the problem. Where the Telecommunica. tions are in accustomed to reckoning on longterm profitability, private operators are ready to sacrifice social innovation on the altar of immed. iate profits. The fact that the companies in ques. tion are all in charge of the traditional urban utilities (water distribution, sewage, equipment), only reinforces this pejorative image of companies of "independent means." Now that there has been time to observe real management of the networks for a few months, the considerable revisions in the ambitions of local programming represent a confirmation of this judgment, as does the mistrust of the operators with respect to the new forms of local expression ${ }^{25}$.

Over and beyond the polemical assessments of cable partners presented above, the problem of a meeting between two different concepts of territory must here be established.

It can be stated, for purposes of simplification, that the administration essentially conceives of territory (here, local and urban) as the final result of its networks. As undifferentiated terminal, a local territory is not susceptible to adap. tation, to negotiation or to being taken as a whole. It is only one of the points, submitted to the traditional territorial realignment ${ }^{26}$, of the deployment of public service and of its network.

On the other hand, the operators of cable, in the logic of their industrial apprehension of urban territory, conceive of the local territory as a point of departure. The constitution of small, specific companies for each locality is in fact illusory: only a few groups (three, in this case) have divided up the entire national market. But there is here a fundamental divergence in approach. A given locality is a territory for several networks, and especially for 2 multitude of profitable urban services (like water and public works) or at least for strategic services (such 2s cable, to be pre. cise). Seen from this point of view, the operators do not conceive of cable except as one element among others in an urban system, seen as negoti. able and able to be taken as a whole in this space. This thesis allows us to explain why these firms are proposing cable in particular in cities where a deficit in the networks is unavoidable: the mechanisms of compensation between mar. 
kets and between services makes it potentially profitable. For example, the capacity of an operator to take over the deficit cabling of a city could constitute a valuable asset in the hypo. thesis of a privatization of the municipal water service, with a view to a market transfer.

Whereas the administration is a "prisoner" of its unique network, the operators are dependent on the complementarity of different networks. Cable is the first point in the meeting of these two opposed concepts of local territory. It explains in part the incapacity of the model of mixed policies to grasp it. There is not any local negotiation here: the actors intervene onto every level of intervention without any particular political administrative kinship. There is also an absence of local political resistence to change: the local representatives, on the contrary, are frequently in the avant garde of modernization, anxious to get ahead of their urban rivals.

In this type of public policy, the local representatives assume responsibility for linking the different sorts of logic which equip their territory and give it meaning. Aside from the traditional resources at their disposal (privileged access to administration, mastery of urban political relations, accumulation of mandates...) they have the responsibility of making coherent the different technical, economic, and social interventions at the local level.

The best illustration of this mission of territorial policy of networks is the curious destiny of the Plan-câble. The integration of three networks into one has ceded to a new break-up. The ISDN (Integrated Services Digital Network) is no lon. ger the objective, even in the long run, of cable. It is deployed in parallel fashion, on another support system. Local television channels, in Toulouse for example, are returning to Herzian space. This network break-up is also the sign of a differentiated taking of responsibility on the local level. The municipalities are no longer the only ones interested in cable. The Regional and even Departmental authorities are beginning to study and develop new types of policies. In this, ac. cording to the executives concerned, there is the expression of a necessity: existence through the spreading out of communications networks.
Thus, in the Languedoc-Roussillon area, the Conseil Régional is actively contributing to the establishment of the ISDN and in the installation of a Centre de Communication Nouvelles; the Conseil Général of Hérault is developing a depart. mental cable network; and the City of Montpellier is working on an advanced urban cable network. These telecommunications networks are the objects and the subjects of two-fold competition: that of the relevance of the administrative territory, and that of the assertion of the local political personnel.

In this shift in the Plan-cable, and even in its failure, the telecommunications administration has nonetheless accomplished a transition of some interest: from the management of a single unitary network to several parallel networks, and from the unity of the clientele (subscribers) to taking into account the diversity of administrative territories. This is a considerable evolution, still going on today, which explains some of the uncertainty which weighs upon it.

Defining urban territory as the sedimentation of social, political and technical practices "into networks," avoids on the one hand a fixed and idealistic vision of territory, in its naturai limits as in its institutionalized figures. The evolution of "territorial formations" 27 is based on that of "networking" formations."

On the other hand, there is also a reintroduction of political space into the concrete management of the way networks are linked together. The role of locally elected officials in the rapid develop. ment of new services, far from being outlandish or incidental, appears fundamental to us. The evolution of the local political personnel, from notables to managers, depends party upon this evolution in urban expertise. The new urban and regional elite is sociologically marked by this development in public urban management ${ }^{28}$.

Local political communication thus goes hand in glove with the progressive invisibility of services in networks. The image of local politics used to be embodied in a problematic of public equip. ment which was visible and legitimizing. Today, it tends to be identified with the development of invisible services (Cable, data networks, tech. 
nopolis...), which have the point in common of being conceived as networks.

Communication policies (marketing strategies, exponential diffusion of the image of cities...) are precisely grounded so as to make visible and coherent, among themselves in a given territory, these different networks of invisible services. In other words, what is at stake in local politics is the acquisition of competence in the linking of networks.

This competence presupposes the existence of network-territory regulations, and not the linear imposition of deterritorialized modes of technical networks. The penetration of new networks and serves does not depend on technical factors, but is equally the function of an accumulated history of social and political networks which have their own logic of territorial anchoring

Territorial-network policies are precisely the fruit of this necessary combination or linking of net. works (technical, political, and social) which are heterogeneous and interactive. This is what we call the dialectics of territorialization.

Translated by Judith Crews

\section{Notes}

1. G. DUPUY, "Villes, systèmes et reseaux. Le rôle historique des techniques urbaines," Arrales de la Recbercbe Urbaine, no. 23.24 (1984).

2. G. DUPUY, Systèmes, néseaux, et territoires. Principes de réseautique territoriale (Paris: Presses de l'Ecole Nationale des Ponts et Chaussées, 1985).

3. It will be recalled that it was due to the absence of a legal limit on the extension of the network that the Conseil Constitutionnel had ruled that law $n^{\circ} 84.743,1$ August 1984, was unconstitutional (decision $n^{\circ} 84$, DC, 26 July 1984). The legislators had set the limits in a symptomatically arbitrary fashion at $60 \mathrm{~km}$ and a maximum distance of two départements (law $n^{\circ} 84-1287,31$ December 1984).

\section{P. ALLIES, L'Invention du territoire (Grenoble: Presses Universitaires de Grenoble, 1980).}

5. In like manner, it was also the "bad" quality of the communications networks which justified, among other things, France's being a representative system rather than a democracy for the "father" of French national political will. Cf. E. SIEYES, "Discours a l'Assemblec Nationale," session of 7 September 1789, Arcbives Parlementaires, T. VIII, pp. 594-595. There is much to be said concerning the "electronic agora" which has finally been made possible thanks to the "perfection" of the Teletel network; of. P. CHAMPAGNE, "L'heure de verite," Actes de la Recberebe en Sciences Sociales (1988), Pp. 71-72. 1986).

6. M. ABELES, "L'anthropologue et le politique," in Antbropologie, Etat des lieux. Revue L'Homme, no. $97-98$ (Paris,

7. "...by this means, and with the help of a few other modern discoveries such as the telegraph, it will become easy to govern the greater part of the continents which border the Mediterranean with the same unity, and the same instantaneousness which today exists in France...." M. CHEVALLIER, "Le système de la Méditerrante", Le Globe, January-February 1832. Quoted by I. GOKALP, "Reflecions sur L notion de rtseau artificiel," Bulletin de l'Idate, no. 13 (October 1983).

8. M. MARIE, Un territoire sans mom (Méridiens, 1982).

9. This term, analogous to les trois glonieuses (27, 28 and 29 July 1830), refers to the three decades of economic expansion which marked the post-war period in France (1950's, 60's and 70's) (Tr. note).

10. P. GREMION, Le pouvoir peripbtrique (Paris: Seuil, 1976).

11. C. de GOURNAY, "Les modalites spatiales du développement des reseaux en France et en Grande Brelagne," in Reure Reseaux CNET.UST, no. 4 (1984). 
12. P. NLIES, "Le local, l'Etat et la societé civile," in "Espaces, jeux et enjeux," Nouvelle encyclopédie des sciences et tecbriques (Fondation Diderot Fayard, 1986).

13. 1. GOKALP, op.cit.

14. E. NEGRIER, thesis on "Les politiques locale de cablage."

15. Y. BAREL: "Le social et ses territoires," in Espaces, jeux at enjeux, op. cit. This same idea can be found in the utiliza. tion of the notion of "proxemie" in M. MAFFESOL, "Le temps des tribus" (Méridiens Kincksieck, 1988).

16. B. STIEGER, "Réseaux et communautes," in Armales de la Recbercbe Unbaime, no. 34 (1987).

17. A CAUQUELIN, "Concept pour un passage," Quademi, no. 3.

18. In political science, sce for emple J.L. BODIGUEL and L. ROUBAN, "La dysfonction publique ou la crise du corporatisme," Reure Française de Science Politique, no. 4 (August 1987). In anthropology, see M. ABELES, "Les chemins de la decentralisation," Les Temps Modermes, no. 463 (February 1985).

19. L. SFEZ, Critique de la communication (Paris: Seuil, 1988).

20. According to C. de GOURNAY, there exists a specificity in the French development of networks, notably with respect to English and American models. Where Plan-cable leans directly on the local government in order to establish the dynamics of cable, Great-Britain takes "extreme" care to avoid any intervention by territorialized authorities. Cf. C. de GOURVAY, op. cit.

21. This is the option defended by J. NAISBITT, Megatrends (London: Futura, 1984). He opposes chronologically societies which are contemporary, pyramidal, and in crisis, with the "network-able" ones of the future.

22. The analysis rests on our thesis work. E. NEGRIER, "La maitrise locale des reseaux de communication. Le cas des politiques publiques de cablage a Met, Montpellier et Rennes," Thesis in Political Science, Université de Montpellier 1 , 1989.

23. For example, the obligation to limit the curve in transporting the fibre (to avoid breaking it) leads to unforeseen labor. In the same way, the restraints imposed by the recycling of traditional telecommunications sub-contractors in this net technique raises problems of technical know-how and work control. Thus, the hazands of start-up (buildings which are officially supposed to be cabled, but where lines have been stacked in the basement; or the overlooking of certain "islands" reputed by the agents to be socially unworthy (!)...) can have serious consequences, such as the lengthy occultation of an entire zone of habitation. In all, where the telecommunications administration homed to recuperate $60 \%$ of its telephone network for the tiansportation of optical fibre, it has recovered only 35\%. On this point, see J. RISSON, "Coût des réseaux de vidécommunication," SPES-DGT (November 1987).

24. The name of the French telecommunications administration after 1988.

25. See, on this point, our thesis. The requirement stipulating local production and access to the antenna is now a dead letter in most of the networks.

26. This element is particularly interesting in the evolution of Plan-cable. The first agreements signed between the administration and local groups indicated that every cabled site would have the right to obtain an agreed-on advantage to another site. This is what is alled the clause of the "most-favoured S.L.E.C." clause. This illustration of the principle of realignment (when the map of the sites to be cabled shows that the immense majority of average-sized cities are in fact excluded, introducing a large territorial inequality) was legally abandoned as early as June 1986. Nevertheless, it continues to play a role, both in the hesitations of France-Télecom to negotiate local arrangements, and in the attitude of operators towards elected representatives. For example, this statement from one of the elected representatives in charge of cable for the city of Montpellier: "I have come to realize that the CGE frequently led me to believe that such and such a city had gotten a preferential rate, to toy to make me put pressure on the DGT - when it was untrue!" M. LEVITA, interview June 1988.

27. By analogy with the concept of social formation elaborated by N. POULANTZAS in Les classes sociales dans le capitalisme d'aujourd'bui (Paris: Seuil, 1974), p. 25.

28. See P. GARRAUD, "Intégration et différenciation dans le personnel politique français: l'exemple des maires urbains 1945-1984," Diss. Université de Bordeaux, 1987. 